\title{
Shallow-ocean methane leakage and degassing to the atmosphere: triggered by offshore oil-gas and methane hydrate explorations
}

\author{
Yong Zhang ${ }^{1 *}$ and Wei-Dong Zhai ${ }^{2}$ \\ ${ }^{1}$ Key Laboratory of Coastal Zone Environmental Processes and Ecological Remediation, Yantai Institute of Coastal Zone \\ Research, Chinese Academy of Sciences, Yantai, China, ${ }^{2}$ Department of Marine Chemistry, National Marine Environmental \\ Monitoring Center, Dalian, China
}

\section{OPEN ACCESS}

Edited by:

Sunil Kumar Singh,

Physical Research Laboratory, India

Reviewed by:

Arvind Singh,

GEOMAR Helmholtz Centre for Ocean

Research Kiel, Germany

Sanjeev Kumar,

Physical Research Laboratory, India

${ }^{*}$ Correspondence: Yong Zhang,

Key Laboratory of Coastal Zone Environmental Processes and

Ecological Remediation, Yantai Institute of Coastal Zone Research, Chinese Academy of Sciences, 17,

Chunhui Road, Laishan District, Yantai 264003, China yzhang@yic.ac.cn

Specialty section:

This article was submitted to Marine Biogeochemistry,

a section of the journal Frontiers in Marine Science

Received: 11 February 2015 Accepted: 19 May 2015 Published: 29 May 2015

Citation:

Zhang $Y$ and Zhai W-D (2015) Shallow-ocean methane leakage and degassing to the atmosphere:

triggered by offshore oil-gas and methane hydrate explorations.

Front. Mar. Sci. 2:34.

doi: 10.3389/fmars.2015.00034
Both offshore oil-gas exploration and marine methane hydrate recovery can trigger massive $\mathrm{CH}_{4}$ release from seafloor. During upward transportation of $\mathrm{CH}_{4}$ plume through water column, $\mathrm{CH}_{4}$ is subjected to dissolution and microbial consumption despite the protection of hydrate and oil coating on bubbles surface. The ultimate $\mathrm{CH}_{4}$ degassing to the atmosphere appears to be water-depth dependent. In shallow oceans with water depth less than $100 \mathrm{~m}$, the natural or human-induced leakages or both lead to significant sea-to-air $\mathrm{CH}_{4}$ degassing from 3.00 to $1.36 \times 10^{5} \mu \mathrm{mol} \mathrm{m} \mathrm{m}^{-2} \mathrm{~d}^{-1}$. To quantify the human-perturbation induced $\mathrm{CH}_{4}$ degassing, the combination of top-down modeling and bottom-up calculations is essential due to spatial and temporal variability of diffusion and ebullition at water-air interface.

Keywords: methane, seafloor leakage, offshore oil-gas exploration, hydrate, coastal process

\section{Introduction}

Methane $\left(\mathrm{CH}_{4}\right)$ is an infrared-active trace gas that plays an important role in Earth's climate system (Lelieveld et al., 1998). Despite its low mole fraction in the atmosphere (1.803 ppm in 2011), $\mathrm{CH}_{4}$ is the second largest contributor (17\%, after carbon dioxide) to the total radiative forcing caused by the well-mixed greenhouse gases (IPCC, 2013). The continuous increase of atmospheric $\mathrm{CH}_{4}$ in the past decades implies an imbalance between $\mathrm{CH}_{4}$ sources and sinks and prompts urgent questions about the causes (Cicerone and Oremland, 1988; Kirschke et al., 2013; Nisbet et al., 2014).

Although earlier researchers suggest that natural emissions of $\mathrm{CH}_{4}$ from oceans may only contribute $1 \%$ to the global atmospheric methane budget (Bange et al., 1994; Judd et al., 2002; U.S. EPA, 2012), recently the oceanic $\mathrm{CH}_{4}$ release has received increasing attention under the context of global warming induced Arctic changes (e.g., Whiteman et al., 2013). So far, understanding the maintaining mechanism and variability of the sea-to-air flux of $\mathrm{CH}_{4}$ remains a huge challenge since most potential source areas of $\mathrm{CH}_{4}$ are still insufficiently sampled in global oceans (Achterberg, 2014). It is worth noting that marine sediments serve as the global largest reservoir of $\mathrm{CH}_{4}$ (Kvenvolden, 2002; Milkov, 2004). If a substantial amount of $\mathrm{CH}_{4}$ were released from seafloor, the atmospheric $\mathrm{CH}_{4}$ concentration would rise dramatically.

As strong anthropogenic perturbations, offshore oil-gas explorations and marine methane hydrate explorations may play an important role in triggering the $\mathrm{CH}_{4}$ release from seafloor. The well sites, processing plants, storage tanks, transmission compressor stations, and distribution systems may act as "super-emitter" $\mathrm{CH}_{4}$ sources, which have been considered to be a cause for larger $\mathrm{CH}_{4}$ emissions from North American natural gas systems than official estimates (Brandt et al., 2014). 
Nowadays preventing $\mathrm{CH}_{4}$ release from vented and flared natural gas has received considerable attention (e.g., Elvidge et al., 2009; U.S. GAO, 2010), while the $\mathrm{CH}_{4}$ degassing associated with episodic $\mathrm{CH}_{4}$ leakage from seafloor is also identified (e.g., $\mathrm{Du}$ et al., 2014; Zhang et al., 2014). This mini review summarized recent progresses regarding the $\mathrm{CH}_{4}$ leakage from seafloor caused by offshore oil-gas and marine methane hydrate explorations and its degassing to the atmosphere.

\section{Offshore Oil-Gas Exploration and $\mathrm{CH}_{4}$ Leakage}

To meet energy demands in both developed and emerging economies, the offshore oil and gas exploration has received international attentions in recent decades. In 2012, the offshore discovery accounted for $90 \%$ of world newly increased reserves (Zhao et al., 2014). The newly discovered oil-gas reservoirs concentrated in the coastal shallow waters (Figure 1). In addition to offshore boom in the Gulf of Mexico, substantial exploration and development has taken place along coasts of Brazil and the Africa. Interests in the oil-gas exploration in the more challenging Arctic area are also increasing.

Oil and gas can enter the marine environment by natural seepage and/or by leaks and spills caused by human activities (extraction, transportation, etc.). The natural crude-oil seeps scatter in global coastal seas and the amount of global seepage is estimated to be 600,000 tons per year (Kvenvolden and Cooper, 2003). Natural gas seepage has been considered to be the cause of strong subsurface $\mathrm{CH}_{4}$ anomaly in the Davis Strait, North Atlantic Ocean (Punshon et al., 2014).

Compared to natural seepage, marine oil and gas extraction can cause disastrous oil spills and leakages accompanied by massive $\mathrm{CH}_{4}$ injections into the overlying water column. Some "landmark" accidents include Ekofish B blowout in the North
Sea in 1977, Ixtoc I blowout in the Gulf of Mexico in 1979, Adriatic IV blowout in the Mediterranean Sea in 2004, Montara blowout in the Timor Sea in 2009, and Macondo blowout in the Gulf of Mexico in 2010 (Christou and Konstantinidou, 2012). Additionally, $\mathrm{CH}_{4}$ leakage may occur at any subsea facility, such as the pipeline, the flange, the valve and the weld (Vrålstad et al., 2011). $\mathrm{CH}_{4}$ emissions from oil and gas systems (including coastal and offshore) were estimated to be $23 \%$ of total global anthropogenic emissions in 2010 and they are expected to grow $26 \%$ from 2010 to 2030 (U. S. EPA, 2012).

Undoubtedly, reducing $\mathrm{CH}_{4}$ emission from oil and gas systems has environmental and economic benefits, especially in the Arctic. This issue has been seriously considered by some national governments and non-governmental organizations (e.g., the Global Methane Initiative, https://www.globalmethane.org/).

\section{Marine Methane Hydrate Exploration and Potential $\mathrm{CH}_{4}$ Leakage}

Huge quantities of $\mathrm{CH}_{4}$ are stored in continental margins in the form of methane hydrates under a delicate balance of low temperature (around $0^{\circ} \mathrm{C}$ ) and high hydrostatic pressure (a few MPa) (Sloan and Koh, 2008). Methane hydrate (also called gas hydrate) is an ice-like crystalline form of water and lowmolecular-weight gas (mainly $\mathrm{CH}_{4}$ ) with a nominal composition of $\left(\mathrm{CH}_{4}\right)_{4}\left(\mathrm{H}_{2} \mathrm{O}\right)_{23}$. One cubic meter of fully saturated methane hydrate solid contains $\sim 164 \mathrm{~m}^{3}$ of $\mathrm{CH}_{4}$ gas at the standard temperature and pressure (Kvenvolden, 1993).

The methane hydrate has been found on nearly all major continental shelves (Figure 1). Its reserves are estimated to be 3000-4000 times today's atmospheric $\mathrm{CH}_{4}$ reservoir (MacDonald, 1990; Blunier, 2000) or twice the existing reserves of all fossil fuels including coal, oil and natural gas (Kvenvolden, 1993, 2002).

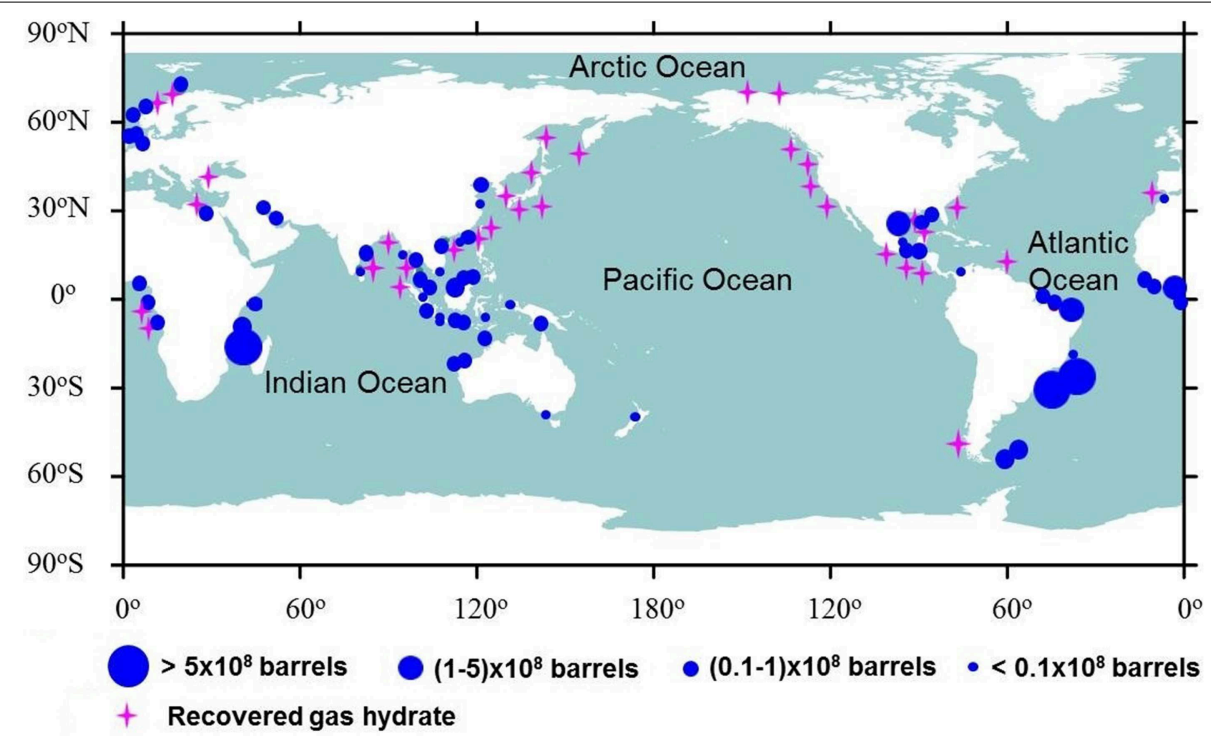

FIGURE 1 | The global new discoveries of offshore oil-gas exploration (Zhao et al., 2014) and an inventory of marine methane hydrate deposits (Ruppel and Noserale, 2012). Purple star symbols show the gas hydrates that have been discovered, while blue dots show those offshore oil-gas discoveries in 2012. 
Interest in methane hydrate has been growing rapidly since global resources of conventional oil and gas are on the decline and methane hydrate has emerged as a potential resource to make up the expected shortfall of conventional oil and gas (Kvenvolden, 1993; Makogon et al., 2007; Makogon, 2010). The Gas Hydrate Joint Industry Project in the Gulf of Mexico has confirmed the occurrence of methane hydrates below the seafloor of Gulf of Mexico (Boswell et al., 2012). In early 2012, the U.S. and Japan completed a successful field trial of methane hydrate production technologies in the North Slope of Alaska (http://energy.gov/). In March 2013, Japan's Methane Hydrate R\&D Program conducted an experimental operation and succeeded to produce a steady $\mathrm{CH}_{4}$ flow southeast of the Atsumi peninsula, Japan (http:// www.jogmec.go.jp/). Other earlier global drilling efforts and production test studies were summarized by Ruppel (2011). However, so far no large-scale commercial $\mathrm{CH}_{4}$ production from methane hydrate deposits has been reported due to scientific and technical challenges and economic viability.

Methane hydrate may serve as an important factor affecting global climate change because they are unstable and subject to dissociation due to slight temperature or pressure change, causing catastrophic seafloor failure and massive (gigaton scale) $\mathrm{CH}_{4}$ release into overlying ocean-atmosphere system (Kennett et al., 2000; Paull et al., 2003). The release of large volumes of $\mathrm{CH}_{4}$ to the atmosphere could in theory aggravate climate warming and trigger more methane hydrates to destabilize, creating a positive feedback loop. The positive interaction between climate and methane hydrate has been considered to be a cause in triggering the Palaeogene hyperthermal events, an abrupt period of global warming $\left(4-8^{\circ} \mathrm{C}\right.$ temperature rise) between 57 and 50 million years ago (Dickens et al., 1995; Kaiho et al., 1996; Gu et al., 2011) and the Late Quaternary (400,000-10,000 years ago) climate change (Kennett et al., 2003).

Without anthropogenic perturbation, most of the world's methane hydrate deposits should remain stable for the next few thousand years (Ruppel and Noserale, 2012). However, marine methane hydrate dissociation in response to ocean warming has been reported in many coastal seas, including the offshore Costa Rica (Crutchley et al., 2014), the offshore southwestern Japan (Bangs et al., 2010), the south Kara Sea shelf (Portnov et al., 2013), the northern U.S. Atlantic margin (Skarke et al., 2014), the offshore Svalbard (Westbrook et al., 2009; Marín-Moreno et al., 2013; Berndt et al., 2014) and sub-sea permafrost-associated methane hydrates in the east Siberian Arctic shelf (Shakhova et al., 2010). U.S. EPA (2012) suggested that the increase of $\mathrm{CH}_{4}$ leakage from methane hydrate due to ocean warming may have overcome the barrier of water column and resulted in a significant atmospheric $\mathrm{CH}_{4}$ load. How to evaluate the risks of the future commercial exploitation induced submarine geohazards and the consequently massive $\mathrm{CH}_{4}$ release remains an open question.

\section{Behavior of Seafloor-Released $\mathrm{CH}_{4}$}

The seafloor-released $\mathrm{CH}_{4}$ will migrate upward through the water column either as dissolved $\mathrm{CH}_{4}$ or as bubble $\mathrm{CH}_{4}$. The rising $\mathrm{CH}_{4}$ plume in the water column tends to get weak since some
$\mathrm{CH}_{4}$ are subject to dissolution and microbially-mediated aerobic and anaerobic oxidation (Greinert et al., 2006; Reeburgh, 2007; Römer et al., 2012). The remaining fraction can reach atmosphere through diffusion or ebullition, which is determined by water depth, stratification, and microbiological processes within the water column (Schmale et al., 2005; Mau et al., 2007). Clarifying the behavior of $\mathrm{CH}_{4}$ in the water column is critical to constrain the hazard potential of offshore drilling activities.

For $\mathrm{CH}_{4}$ bubbles emanated from seafloor, the upward migration and dissolution of $\mathrm{CH}_{4}$ is highly dependent on hydrate or oil coverage on bubbles surface. Both field and lab experiments have demonstrated that $\mathrm{CH}_{4}$ bubbles are likely to be coated by methane hydrate within the local methane hydrate stable field (MHSF), which can significantly decrease but does not halt $\mathrm{CH}_{4}$ dissolution (Rehder et al., 2002, 2009; Warzinski et al., 2014). The bubbles usually dissolve rapidly at the upper boundary of the local MHSF, which is jointly determined by water temperature, salinity, and gas composition (Römer et al., 2014). When $\mathrm{CH}_{4}$ spills are accompanied by oil, oil coating around rising bubbles also impedes dissolution, thereby enhancing the likelihood of $\mathrm{CH}_{4}$ release to the atmosphere (De Beukelaer et al., 2003; Leifer and MacDonald, 2003; Körber et al., 2014).

In deep waters, the scenario is outlined by the Deepwater Horizon oil spill event. From 20 April to 15 July 2010, $9.14 \times 10^{9}$ to $1.25 \times 10^{10}$ moles of $\mathrm{CH}_{4}$ were injected into deep waters $(\sim 1500 \mathrm{~m})$ of Gulf of Mexico (Kessler et al., 2011). However, only a few (less than $0.01 \%$ ) of the seafloor-released $\mathrm{CH}_{4}$ escaped into atmosphere (Yvon-Lewis et al., 2011). The $\mathrm{CH}_{4}$ plume was trapped below $800 \mathrm{~m}$ depth with $\mathrm{CH}_{4}$ concentrations roughly 20-50 times as high as background levels and the microbial $\mathrm{CH}_{4}$ oxidation rate quantified to be $10 \mathrm{nmol} \mathrm{d}^{-1}$ (the median value) therein (Valentine et al., 2010). The trapped $\mathrm{CH}_{4}$ was consumed by methanotrophic bacteria within $\sim 120$ days from the onset of release, resulting in significant oxygen anomaly in deep waters (Valentine et al., 2010; Kessler et al., 2011). By comparing the amounts of $\mathrm{CH}_{4}$ microbial consumed and degassed to the atmosphere, Kessler et al. (2011) suggested that methanotrophic bacterial communities act as a dynamic biofilter that respond quickly and efficiently to the seafloor $\mathrm{CH}_{4}$ leakage.

In the waters with depth around the upper boundary of local MHSZ, no oil-gas spill event has been reported so the scenario can only be described by some simulated experiments. A gas blowout experiment was conducted in the Norwegian Sea in 2000, during which $\sim 4 \times 10^{5}$ mole of $\mathrm{CH}_{4}$ was discharged into the water column of $844 \mathrm{~m}$ depth. Since no methane hydrates shell was formed around gas bubbles, the gas dissolved quickly in the water column and no gas bubble was observed at sea surface (Johansen et al., 2003). Schmale et al. (2011) assumed a massive short-term injection of $\mathrm{CH}_{4}$ release $\left(1.1 \times 10^{10}\right.$ mole $)$ at depth of $700 \mathrm{~m}$ in the Black Sea. They modeled that $\mathrm{CH}_{4}$ was effectively buffered by microbial consumption and hammered by water column stratification. The simulated $\mathrm{CH}_{4}$ release in depth resulted in only a $2-3 \%$ increase in the sea-to-air flux.

The shallow-ocean $\mathrm{CH}_{4}$ leakage presents a quite different scenario. By studying oil spills in the Bohai Sea (China) with water depth less than $30 \mathrm{~m}$, Zhang et al. (2014) revealed that the seafloor-released $\mathrm{CH}_{4}$ can break through the summer 
stratification, increasing sea surface $\mathrm{CH}_{4}$ concentration by up to 4.7 times and enhancing local $\mathrm{CH}_{4}$ outgassing by up to 14.6 times. However, the function of methanotrophs in this shallow sea is still unknown.

According to McGinnis et al. (2006), most marine sources of the atmospheric $\mathrm{CH}_{4}$ are located in shallow oceans with water depth less than $100 \mathrm{~m}$. This is coincident with the surfacewater $\mathrm{CH}_{4}$ distribution in the Black Sea, where elevated $\mathrm{CH}_{4}$ concentrations were only observed above seeps areas with depth $<100 \mathrm{~m}$ and no significant imprint was observed above high-intensity seeps with water column deeper than $150 \mathrm{~m}$ (Schmale et al., 2005). Summarizing sea-to-air $\mathrm{CH}_{4}$ fluxes from marine environments affected by oil-gas exploration and methane hydrate dissociation (Table 1), we can also find that shallow areas (depth of leakage $<100 \mathrm{~m}$ ) present intensive $\mathrm{CH}_{4}$ fluxes of $3.00-1.36 \times 10^{5} \mu \mathrm{mol} \mathrm{m} \mathrm{m}^{-2} \mathrm{~d}^{-1}$, whereas deeper areas show weaker values of $-3.65-800 \mu \mathrm{mol} \mathrm{m}^{-2} \mathrm{~d}^{-1}$. It is worthy of noting that Solomon et al. (2009) observed that intensive $\mathrm{CH}_{4}$ bubble plumes ascend from depth 550-600 $\mathrm{m}$ to sea surface in the Gulf of Mexico, leading to intensive degassing (up to $10^{4} \mu \mathrm{mol}$ $\left.\mathrm{m}^{-2} \mathrm{~d}^{-1}\right)$. So water depth may not serve as the only threshold of the $\mathrm{CH}_{4}$ degassing.

\section{Quantifying $\mathrm{CH}_{4}$ Degassing}

Leakage of $\mathrm{CH}_{4}$ from seafloor triggered by offshore explorations may contribute directly to atmospheric $\mathrm{CH}_{4}$ budgets and possibly accelerate global warming (Jiang et al., 2006; Biastoch et al., 2011).
However, so far the global or regional sea-to-air $\mathrm{CH}_{4}$ fluxes are poorly constrained, leading to uncertainties in carbon cycle and climate models.

The approaches to quantify $\mathrm{CH}_{4}$ degassing generally fall into two categories: "bottom-up" calculations and "top-down" modeling (also known as inverse modeling). The bottom-up estimation of the $\mathrm{CH}_{4}$ leakage rate is based on summing up emissions from different types of known sources (Olivier, 2002). $\mathrm{CH}_{4}$ can enter the atmosphere by diffusion of dissolved $\mathrm{CH}_{4}$ across the water-air interface or by direct migration of bubbles (if still contains $\mathrm{CH}_{4}$ ). As for diffusion, the sea-air flux is estimated using a stagnant laminar layer model proposed by Liss and Slater (1974). Its reliability lies not only on gas transfer velocity and hydrodynamic conditions (Wanninkhof et al., 2009; Johnson et al., 2011), but also on the spatial resolution of sample collections. The surface $\mathrm{CH}_{4}$ emission hot spots (i.e., areas of high flux) need to be covered (Du et al., 2014; Zhang et al., 2014). Compared to diffusion, ebullition of $\mathrm{CH}_{4}$-containing bubbles, especially a small fraction of the largest bubbles, may release larger amounts of $\mathrm{CH}_{4}$ and exhibits much greater spatiotemporal variation (Greinert and Nützel, 2004; McGinnis et al., 2014; Xiao et al., 2014; DelSontro et al., 2015). Floating chamber method has been widely used for direct measurement of both diffusive and ebullitions fluxes at water-air interface, but mostly in lakes and estuaries. Its utilization at sea is greatly challenged due to insufficient temporal and spatial coverage. At extreme shallow coastal waters $(<5 \mathrm{~m})$, a submerged chamber device has been developed for in-situ and on-line measurement of $\mathrm{CH}_{4}$ flux

TABLE 1 | Sea-to-air $\mathrm{CH}_{4}$ fluxes from marine environments affected by oil-gas exploration and methane hydrate dissociation.

\begin{tabular}{|c|c|c|c|c|}
\hline Method & Location & Depth of leakage (m) & Flux $\left(\mu \mathrm{mol} \mathrm{m}^{-2} \mathrm{~d}^{-1}\right)$ & References \\
\hline & DIFFUSIVE NET FLUXES & & & \\
\hline & Plume area during the Deepwater Horizon oil spill & 1500 & $0.024^{\mathrm{a}}$ & Yvon-Lewis et al., 2011 \\
\hline & Seeps area in the northern Gulf of Mexico & $550-1250$ & $-3.65-75.0^{\mathrm{a}}$ & Hu et al., 2012 \\
\hline & Seeps area in the northern Gulf of Mexico & $550-600$ & $61.9-10,500^{b}$ & Solomon et al., 2009 \\
\hline & North Sea & $<700$ & $-0.38-6.7^{\mathrm{C}}$ & Bange et al., 1994 \\
\hline & Baltic Sea & $<460$ & $0.006-800^{c}$ & Bange et al., 1994 \\
\hline & Sea of Okhotsk & $\sim 200$ & $0.36-88^{b}$ & Yoshida et al., 2004 \\
\hline \multirow[t]{9}{*}{ Bottom-up calculation } & Seep area in Black Sea & $>200$ & $40.6-49.2^{b}$ & Schmale et al., 2005 \\
\hline & Seep area in Black Sea & $\sim 90$ & $200^{b}$ & Schmale et al., 2005 \\
\hline & Coal Oil Point & $<70$ & $195^{\mathrm{b}}$ & Mau et al., 2007 \\
\hline & East Siberian Arctic Shelf & $\sim 45$ & $299-982^{b}$ & Shakhova et al., 2010 \\
\hline & Hotspots in the Bohai Sea & $<30$ & $3.00-18.71^{\mathrm{a}}$ & Zhang et al., 2014 \\
\hline & EBULLITION FLUXES & & & \\
\hline & East Siberian Arctic Shelf & $\sim 45$ & $369-1781^{d}$ & Shakhova et al., 2010 \\
\hline & Arctic lakes (Small individual bubbles) & $<25$ & $1563 \pm 750^{\mathrm{e}}$ & Walter et al., 2008 \\
\hline & Arctic lakes (open-hole hotspots) & $<25$ & $(1.36 \pm 0.75) \times 10^{5 e}$ & Walter et al., 2008 \\
\hline Top-down modeling & Offshore platforms in the Southeast Asia & Not mentioned & $0.16^{f}$ & Nara et al., 2014 \\
\hline
\end{tabular}

a Fluxes were calculated using the gas transfer velocity parameterization of Sweeney et al. (2007).

${ }^{b}$ Fluxes were calculated using the gas transfer velocity parameterization of Wanninkhof (1992).

${ }^{c}$ Fluxes were calculated using the gas transfer velocity parameterization of Liss and Merlivat (1986).

${ }^{d}$ Measured indirectly, i.e., total flux minus diffusive flux.

esynthetic aperture radar imagery combined with field investigation.

${ }^{f}$ Includes but not limited to diffusive flux and ebullition emission. 
from seafloor (Di et al., 2014). In the Arctic regions, synthetic aperture radar imagery has been used to locate point-source $\mathrm{CH}_{4}$ ebullition from ice-covered lakes (Walter et al., 2008). Some numerical models have also been developed to quantify direct bubble transport of $\mathrm{CH}_{4}$ (Leifer and Patro, 2002; McGinnis et al., 2006; Yamamoto et al., 2009). Yet more efforts are needed to better quantify $\mathrm{CH}_{4}$ ebullition flux to the atmosphere on the spot, especially at ice-free seas.

Top-down modeling is based on atmospheric $\mathrm{CH}_{4}$ measurements, atmospheric models, and statistical tools to invert concentration fields into parameters that provide the estimation of $\mathrm{CH}_{4}$ emissions and sinks (Olivier, 2002). The remote-sensing-based top-down approach has been used to quantify $\mathrm{CH}_{4}$ emission fluxes from the North American inland natural gas sites (Kort et al., 2014; Schneising et al., 2014). So far only a few similar investigations are designed to constrain $\mathrm{CH}_{4}$ emissions from offshore oil-gas production. For example, Nara et al. (2014) have estimated $\mathrm{CH}_{4}$ emission rates from offshore oil and gas platforms in the Southeast Asia based on their observed atmospheric $\mathrm{CH}_{4}$ peaks and a mass balance approach. Similar atmospheric $\mathrm{CH}_{4}$ peaks were also revealed at two regional atmospheric background monitoring sites adjacent to the Bohai Sea shortly after an oil-spill accident in June-August 2011 (Zhang et al., 2014). The field-data-based top-down approach is worth to be seriously applied.

Satellite observations are able to monitor gas emissions down to the point-source scale (Velazco et al., 2011). Airborne imaging spectrometry has the potential to provide high resolution mapping of marine $\mathrm{CH}_{4}$ emissions from point sources (Thorpe et al., 2013). So time-resolved satellite observation supplemented by aircraft and ground-based measurements may provide a feasible method to quantify the large scale $\mathrm{CH}_{4}$ emission from offshore oil-gas exploration areas.

According to the limited literature data that have already been summarized in Table 1, ebullition fluxes generally show

\section{References}

Achterberg, E. P. (2014). Grand challenges in marine biogeochemistry. Front. Mar. Sci. 1:7. doi: 10.3389/fmars.2014.00007

Bange, H. W., Bartell, U. H., Rapsomanikis, S., and Andreae, M. O. (1994). Methane in the Baltic and North Seas and a reassessment of the marine emissions of methane. Global Biogeochem. Cycles 8, 465-480. doi: 10.1029/94GB02181

Bangs, N. L., Hornbach, M. J., Moore, G. F., and Park, J. O. (2010). Massive methane release triggered by seafloor erosion offshore southwestern Japan. Geology 38, 1019-1022. doi: 10.1130/G31491.1

Berndt, C., Feseker, T., Treude, T., Krastel, S., Lievetrau, V., Niemann, H., et al. (2014). Temporal constraints on hydrate-controlled methane seepage off Svalbard. Science 343, 284-287. doi: 10.1126/science. 1246298

Biastoch, A., Treude, T., Rupke, L. H., Riebesell, U., Roth, C., Burwicz, E. B., et al. (2011). Rising Arctic Ocean temperatures cause gas hydrate destabilization and ocean acidification. Geophys. Res. Lett. 38, L08602. doi: 10.1029/2011GL047222

Blunier, T. (2000). "Frozen" methane escapes from the sea floor. Science 288, 68-69. doi: $10.1126 /$ science. 288.5463 .68

Boswell, R., Collett, T. S., Frye, M., Shedd, W., McConnell, D. R., and Shelander, D. (2012). Subsurface gas hydrates in the northern Gulf of Mexico. Mar. Petrol. Geol. 34, 4-30. doi: 10.1016/j.marpetgeo.2011.10.003 much higher values than diffusive ones and both of them show great spatial variation. However, so far ebullition measurements are seldom conducted at sea, probably due to their episodic occurrence and lack of method, especially at ice-free seas. Inverse modeling observations are even fewer. Therefore, the current investigations from a few scattered sites are quite insufficient to obtain a global estimation of the $\mathrm{CH}_{4}$ emission triggered by offshore oil-gas and methane hydrate explorations.

\section{Summary}

Massive $\mathrm{CH}_{4}$ leakage from seafloor can be triggered by both offshore oil-gas explorations and marine methane hydrate recovery. Both field investigations and model results showed that $\mathrm{CH}_{4}$ leakage from seafloor, especially from shallow seafloor with depth less than $100 \mathrm{~m}$, may have affected the atmospheric $\mathrm{CH}_{4}$ budget. The shallow-ocean $\mathrm{CH}_{4}$ degassing should be considered in the policy-making on the greenhouse gas mitigation and pollution abatement. While the potential consequence of possible massive $\mathrm{CH}_{4}$ release due to commercial methane hydrate exploration in the near future is still unknown and should be fully considered.

To quantify the oceanic $\mathrm{CH}_{4}$ degassing regionally or globally, the combination of "bottom-up" calculation and "topdown" modeling is recommended. However, field monitoring approaches still need to be developed to evaluate $\mathrm{CH}_{4}$ ebullition fluxes at sea.

\section{Acknowledgments}

This research was jointly supported by Key Laboratory for Ecological Environment in Coastal Areas, State Oceanic Administration of China (contract: 201203) and by National Natural Science Foundation of China (grant 41006040).

Brandt, A. R., Heath, G. A., Kort, E. A., O’Sullivan, F., Pétron, G., Jordaan, S. M., et al. (2014). Methane leaks from North American natural gas systems. Science 343, 733-735. doi: $10.1126 /$ science. 1247045

Christou, M., and Konstantinidou, M. (2012). Safety of Offshore Oil and Gas Operations: Lessons from Past Accident Analysis: Ensuring EU Hydrocarbon Supply Through Better Control of Major Hazards. Publication JRC77767. Joint Research Centre, European Commission.

Cicerone, R. J., and Oremland, R. S. (1988). Biogeochemical aspects of atmospheric methane. Global Biogeochem. Cycles 2, 299-327. doi: 10.1029/GB002i004p00299

Crutchley, G. J., Klaeschenb, D., Planertb, L., Bialasb, J., Berndtb, C., Papenbergb, C., et al. (2014). The impact of fluid advection on gas hydrate stability: investigations at sites of methane seepage offshore Costa Rica. Earth Planet. Sci. Lett. 401, 95-109. doi: 10.1016/j.epsl.2014.05.045

De Beukelaer, S. M., MacDonald, I. R., Guinnasso, N. L., and Murray, J. A. (2003). Distinct side-scan sonar, RADARSAT SAR, and acoustic profiler signatures of gas and oil seeps on the Gulf of Mexico slope. Geo Mar. Lett. 23, 177-186. doi: 10.1007/s00367-003-0139-9

DelSontro, T., McGinnis, D. F., Wehrli, B., and Ostrovsky, I. (2015). Size does matter: importance of large bubbles and small-scale hot spots for methane transport. Environ. Sci. Technol. 49, 1268-1276. doi: 10.1021/es50 54286 
Di, P. F., Dong, F., and Chen, D. F. (2014). In-situ and on-line measurement of gas flux at a hydrocarbon seep from the northern South China Sea. Cont. Shelf Res. 81, 80-87. doi: 10.1016/j.csr.2014.04.001

Dickens, G. R., O’Neil, J. R., Rea, D. K., and Owen, R. M. (1995). Dissociation of oceanic methane hydrate as a cause of the carbon isotope excursion at the end of the Paleocene. Paleoceanography 10, 965-971. doi: 10.1029/95PA02087

Du, M., Yvon-Lewis, S., Garcia-Tigreros, F., Valentine, D. L., Mendes, S. D., and Kessler, J. D. (2014). High resolution measurements of methane and carbon dioxide in surface waters over a natural seep reveal dynamics of dissolved phase air-sea flux. Environ. Sci. Technol. 48, 10165-10173. doi: 10.1021/es5017813

Elvidge, C. D., Ziskin, D., Baugh, K. E., Tuttle, B. T., Ghosh, T., Pack, D. W., et al. (2009). A fifteen year record of global natural gas flaring derived from satellite data. Energies 2, 595-622. doi: 10.3390/en20300595

Greinert, J., Artemov, Y., Egorov, V., Batist, M. D., and McGinnis, D. (2006). 1300 -m-high rising bubbles from mud volcanoes at $2080 \mathrm{~m}$ in the Black Sea: hydroacoustic characteristics and temporal variability. Earth Planet. Sci. Lett. 244, 1-15. doi: 10.1016/j.epsl.2006.02.011

Greinert, J., and Nützel, B. (2004). Hydroacoustic experiments to establish a method for the determination of methane bubble fluxes at cold seeps. Geo Mar. Lett. 24, 75-85. doi: 10.1007/s00367-003-0165-7

Gu, G. S., Dickens, G. R., Bhatnagar, G., Colwell, F. S., Hirasaki, G. J., and Chapman, W. G. (2011). Abundant Early Palaeogene marine gas hydrates despite warm deep-ocean temperatures. Nat. Geosci. 4, 848-851. doi: 10.1038/ngeo1301

Hu, L., Yvon-Lewis, S. A., Kessler, J. D., and MacDonald, I. R. (2012). Methane fluxes to the atmosphere from deepwater hydrocarbon seeps in the northern Gulf of Mexico, J. Geophys. Res. 117, C01009. doi: 10.1029/2011JC007208

IPCC. (2013). "Climate change 2013: the physical science basis," in Contribution of Working Group I to the Fifth Assessment Report of the Intergovernmental Panel on Climate Change. Cambridge: Cambridge University Press.

Jiang, G. Q., Shi, X. Y., and Zhang, S. H. (2006). Methane seeps, methane hydrate destabilization, and the late Neoproterozoic postglacial cap carbonates. Chin. Sci. Bull. 51, 1152-1173. doi: 10.1007/s11434-006-1152-y

Johansen, Ø., Rye, H., and Cooper, C. (2003). DeepSpill-Field study of a simulated oil and gas blowout in deep water. Spill Sci. Technol. B 8, 433-443. doi: 10.1016/S1353-2561(02)00123-8

Johnson, M. T., Hughes, C., Bell, T. G., and Liss, P. S. (2011). “A Rumsfeldian analysis of uncertainty in air-sea gas exchange," in Gas Transfer at Water Surfaces 2010, eds S. Komori, W. McGillis, and R. Kurose (Kyoto: Kyoto University Press), 464-485.

Judd, A. G., Hovland, M., Dimitrov, L. I., García, G., and Jukesn, V. (2002). The geological methane budget at continental margins and its influence on climate change, Geofluids 2, 109-126. doi: 10.1046/j.1468-8123.2002.00027.x

Kaiho, K., Arinobu, T., Ishiwatari, R., Morgans, H. E. G., Okada, H., Takeda, N., et al. (1996). Latest Paleocene benthic foraminiferal extinction and environmental changes at Tawanui, New Zealand. Paleoceanography 11, 447-465. doi: 10.1029/96PA01021

Kennett, J. P., Cannariato, K. G., Hendy, I. L., and Behl, R. J. (2000). Carbon isotopic evidence for methane hydrate instability during Quaternary interstadials. Science 288, 128-133. doi: 10.1126/science.288.5463.128

Kennett, J. P., Cannariato, K. G., Hendy, I. L., and Behl, R. J. (2003). Methane Hydrates in Quaternary Climate Change: The Clathrate Gun Hypothesis. Washington, DC: American Geophysical Union.

Kessler, J. D., Valentine, D. L., Redmond, M. C., Du, M., Chan, E. W., Mendes, S. D., et al. (2011). A persistent oxygen anomaly reveals the fate of spilled methane in the deep Gulf of Mexico. Science 331, 312-315. doi: 10.1126/science.1199697

Kirschke, S., Bousquet, P., Ciais, P., Saunois, M., Canadell, J. G., Dlugokencky, E. J., et al. (2013). Three decades of global methane sources and sinks. Nat. Geosci. 6, 813-823. doi: 10.1038/ngeo1955

Körber, J. H., Sahling, H., Pape, T., dos Santos, F. C., MacDonald, I. R., and Bohrmann, G. (2014). Natural oil seepage at Kobuleti Ridge, eastern Black Sea. Mar. Petrol. Geol. 50, 68-82. doi: 10.1016/j.marpetgeo.2013.11.007

Kort, E. A., Frankenberg, C., Costigan, K. R., Lindenmaier, R., Dubey, M. K., and Wunch, D. (2014). Four corners: the largest US methane anomaly viewed from space, Geophys. Res. Lett. 41, 6898-6903. doi: 10.1002/2014GL061503

Kvenvolden, K. A. (1993). Gas hydrates: geological perspective and global change. Rev. Geophy. 31, 173-187. doi: 10.1029/93RG00268
Kvenvolden, K. A. (2002). Methane hydrate in the global organic carbon cycle. Terra. Nova. 14, 302-306. doi: 10.1046/j.1365-3121.2002.00414.x

Kvenvolden, K. A., and Cooper, C. K. (2003). Natural seepage of crude oil into the marine environment. Geo Mar. Lett. 23, 140-146. doi: 10.1007/s00367-0030135-0

Leifer, I., and MacDonald, I. (2003). Dynamics of the gas flux from shallow gas hydrate deposits: interaction between oily hydrate bubbles and the oceanic environment. Earth Planet. Sci. Lett. 210, 411-424. doi: 10.1016/S0012821X(03)00173-0

Leifer, I., and Patro, R. K. (2002). The bubble mechanism for methane transport from the shallow sea bed to the surface: a review and sensitivity study, Cont. Shelf Res. 22, 2409-2428. doi: 10.1016/S0278-4343(02)00065-1

Lelieveld, J., Crutzen, P. J., and Dentener, F. J. (1998). Changing concentration, lifetime and climate forcing of atmospheric methane. Tellus B Chem. Phys. Meteorol. 50, 128-150. doi: 10.1034/j.1600-0889.1998.t01-1-00002.x

Liss, P. S., and Merlivat, L. (1986). “Air-sea gas exchange rates: introduction and synthesis," in The Role of Air-Sea Exchange in Geochemical Cycling, ed P. Buat-Menard (New York, NY: Springer), 113-127.

Liss, P. S., and Slater, P. G. (1974). Flux of gases across the air-sea interface. Nature 247, 181-184. doi: 10.1038/247181a0

MacDonald, G. J. (1990). Role of methane clathrates in past and future climates. Clim. Chang. 16, 247-281. doi: 10.1007/BF00144504

Makogon, Y. F. (2010). Natural gas hydrates-a promising source of energy. J. Nat. Gas Sci. Eng. 2, 49-59. doi: 10.1016/j.jngse.2009.12.004

Makogon, Y. F., Holditch, S. A., and Makogon, T. Y. (2007). Natural gas-hydratesA potential energy source for the 21st century. J. Petrol. Sci. Eng. 56, 14-31. doi: 10.1016/j.petrol.2005.10.009

Marín-Moreno, H., Minshull, T. A., Westbrook, G. K., Sinha, B., and Sarkar, S. (2013). The response of methane hydrate beneath the seabed offshore Svalbard to ocean warming during the next three centuries. Geophys. Res. Lett. 40, 5159-5163. doi: 10.1002/grl.50985

Mau, S., Valentine, D., Clark, J., Reed, J., Camilli, R., and Washburn, L. (2007). Dissolved methane distributions and air-sea flux in the plume of a massive seep field, Coal Oil Point, California. Geophys. Res. Lett. 34, L22603. doi: 10.1029/2007GL031344

McGinnis, D. F., Greinert, J., Artemov, Y., Beaubien, S. E., and Wüest, A. (2006). Fate of rising methane bubbles in stratified waters: how much methane reaches the atmosphere? J. Geophys. Res. 111, C09007. doi: 10.1029/2005JC003183

McGinnis, D. F., Kirillin, G., Tang, K. W., Flury, S., Bodmer, P., Engelhardt, C., et al. (2014). Enhancing surface methane fluxes from an oligotrophic lake: exploring the microbubble hypothesis. Environ. Sci. Technol. 49, 873-880. doi: $10.1021 /$ es503385d

Milkov, A. V. (2004). Global estimates of hydrate-bound gas in marine sediments: how much is really out there? Earth Sci. Rev. 66, 183-197. doi: 10.1016/j.earscirev.2003.11.002

Nara, H., Tanimoto, H., Tohjima, Y., Mukai, H., Nojiri, Y., and Machida, T. (2014). Emissions of methane from off shore oil and gas platforms in Southeast Asia. Sci. Rep. 4:6503. doi: 10.1038/srep06503

Nisbet, E. G., Dlugokencky, E. J., and Bousquet, P. (2014). Methane on the rise-Again. Science 343, 493-495. doi: 10.1126/science.1247828

Olivier, J. G. J. (2002). On the Quality of Global Emission Inventories: Approaches, Methodologies, Input Data, and Uncertainties. Ph.D. thesis, Utrecht University, Wilco BV, Amersfoort.

Paull, C. K., Brewer, P. G., Ussler, W., Peltzer, E. T., Rehder, G., and Clague, D. (2003). An experiment demonstrating that marine slumping is a mechanism to transfer methane from seafloor gas-hydrate deposits into the upper ocean and atmosphere. Geo Mar. Lett. 22, 198-203. doi: 10.1007/s00367-0020113-y

Portnov, A., Smith, A. J., Mienert, J., Cherkashov, G., Rekant, P., Semenov, P., et al. (2013). Offshore permafrost decay and massive seabed methane escape in water depths $>20 \mathrm{~m}$ at the South Kara Sea shelf. Geophys. Res. Lett. 40, 3962-3967. doi: $10.1002 /$ grl.50735

Punshon, S., Azetsu-Scott, K., and Lee, C. M. (2014). On the distribution of dissolved methane in Davis Strait, North Atlantic Ocean. Mar. Chem. 161, 20-25. doi: 10.1016/j.marchem.2014.02.004

Reeburgh, W. S. (2007). Oceanic methane biogeochemistry. Chem. Rev. 107, 486-513. doi: $10.1021 / \mathrm{cr} 050362 \mathrm{v}$ 
Rehder, G., Brewer, P. G., Peltzer, E. T., and Friederich, G. (2002). Enhanced lifetime of methane bubble streams within the deep ocean. Geophys. Res. Lett. 29, 1731. doi: 10.1029/2001GL013966

Rehder, G., Leifer, I., Brewer, P. G., Friederich, G., and Peltzer, E. T. (2009). Controls on methane bubble dissolution inside and outside the hydrate stability field from open ocean field experiments and numerical modeling. Mar. Chem. 114, 19-30. doi: 10.1016/j.marchem.2009.03.004

Römer, M., Sahling, H., Pape, T., Bahr, A., Feseker, T., Wintersteller, P., et al. (2012). Geological control and magnitude of methane ebullition from a high-flux seep area in the Black Sea-the Kerch seep area. Mar. Geol. 319-322, 57-74. doi: 10.1016/j.margeo.2012.07.005

Römer, M., Sahling, H., Pape, T., dos Santos Ferreira, C., Wenzhöfer, F., Boetius, A., et al. (2014). Methane fluxes and carbonate deposits at a cold seep area of the Central Nile Deep Sea Fan, Eastern Mediterranean Sea. Mar. Geol. 347, 27-42. doi: 10.1016/j.margeo.2013.10.011

Ruppel, C. (2011). "Mehtane hydrates and the future of natural gas," in MITEI Natural Gas Report (Supplementary paper No. 4), MIT, MA. Available online at: https://mitei.mit.edu/system/files/Supplementary_Paper_SP_2_4_ Hydrates.pdf

Ruppel, C., and Noserale, D. (2012). Gas Hydrate and Climate Warming-Why a Methane Catastrophe is Unlikely. Sound Waves (USGS Newsletter). Available online at: http://soundwaves.usgs.gov/2012/06/

Schmale, O., Greinert, J., and Rehder, G. (2005). Methane emission from highintensity marine gas seeps in the Black Sea into the atmosphere. Geophys. Res. Lett. 32, L07609. doi: 10.1029/2004GL021138

Schmale, O., Haeckel, M., and McGinnis, D. F. (2011). Response of the Black Sea methane budget to massive short-term submarine inputs of methane. Biogeosciences 8, 911-918. doi: 10.5194/bg-8-911-2011

Schneising, O., Burrows, J. P., Dickerson, R. R., Buchwitz, M., Reuter, M., and Bovensmann, H. (2014). Remote sensing of fugitive methane emissions from oil and gas production in North American tight geologic formations. Earth's Future 2, 1-11. doi: 10.1002/2014EF000265

Shakhova, N., Semiletov, I., Salyuk, A., Yusupov, V., Kosmach, D., and Gustafsson, Ö. (2010). Extenvisve methane venting to the atmosphere from sediments of the east Siberian Arctic shelf. Science 327, 1246-1250. doi: 10.1126/science.1182221

Skarke, A., Ruppel, C., Kodis, M., Brothers, D., and Lobecker, E. (2014). Widespread methane leakage from the sea floor on the northern US Atlantic margin. Nat. Geosci. 7, 657-661. doi: 10.1038/ngeo2232

Sloan, E. D., and Koh, C. A. (2008). Clathrate Hydrates of Natural Gases, $3 r d$ Edn. New York, NY: CRC Press.

Solomon, E. A., Kastner, M., MacDonald, I. R., and Leifer, I. (2009). Considerable methane fluxes to the atmosphere from hydrocarbon seeps in the Gulf of Mexico. Nat. Geosci. 2, 561-565. doi: 10.1038/ngeo574

Sweeney, C., Gloor, E., Jacobson, A. R., Key, R. M., McKinley, G., Sarmiento, J. L., et al. (2007). Constraining global air-sea gas exchange for $\mathrm{CO}_{2}$ with recent bomb ${ }^{14} \mathrm{C}$ measurements. Global Biogeochem. Cycles, 21, GB2015. doi: $10.1029 / 2006 \mathrm{~GB} 002784$

Thorpe, A. K., Roverts, D. A., Bradley, E. S., Funk, C. C., Dennison, P. E., and Leifer, I. (2013). High resolution mapping of methane emissions from marine and terrestrial sources using a Cluster-Tuned Matched Filter technique and imaging spectrometry. Remote Sens. Environ. 134, 305-308. doi: 10.1016/j.rse.2013.03.018

U.S. EPA. (2012). Global Anthropogenic Non- $\mathrm{CO}_{2}$ Greenhouse Gas Emissions: 1990-2030. United States Environmental Protection Agency (EPA) Report (Washington, DC). Available online at: http://www.epa.gov/climatechange/ Downloads/EPAactivities/Summary_Global_NonCO 2 _Projections_Dec2012. pdf

U.S. GAO. (2010). Federal Oil and Gas Leases: Opportunities Exist to Capture Vented and Flared Natural Gas, which would Increase Royalty Payments and Reduce Greenhouse Gases. United States Government Accountability Office (U.S. GAO) Report to Congressional Requesters. GAO-11-34. (Washington, DC). Available online at: http://www.gao.gov/products/GAO-11-34
Valentine, D. L., Kessler, J. D., Redmond, M. C., Mendes, S. D., Heintz, M. B., et al. (2010). Propane respiration jump-starts microbial response to a deep oil spill. Science 330, 208-211. doi: 10.1126/science.1196830

Velazco, V. A., Buchwitz, M., Bovensmann, H., Reuter, M., Schneising, O., Heymann, J., et al. (2011). Towards space based verification of $\mathrm{CO}_{2}$ emissions from strong localized sources: fossil fuel power plant emissions as seen by a CarbonSat constellation. Atmos. Meas. Tech. 4, 2809-2822. doi: 10.5194/amt-42809-2011

Vrålstad, T., Melbye, A. G., Carlsen, I. M., and Llewelyn, D. (2011). Comparison of leak-detection technologies for continuous monitoring of subsea-production templates. SPE Proj. Facil. Constr. 6, 96-103. doi: 10.2118/ 136590-PA

Walter, K. M., Engram, M., Duguay, C. R., Jeffries, M. O., and Chapin, F. S. (2008). The potential use of synthetic aperture radar for estimating methane ebullition from Arctic lakes. J. Am. Water Res. Ass. 44, 305-315. doi: 10.1111/j.17521688.2007.00163.x

Wanninkhof, R. (1992). Relationship between wind speed and gas exchange over the ocean. J. Geophys. Res. 97, 7373-7382. doi: 10.1029/92JC00188

Wanninkhof, R., Asher, W. E., Ho, D. T., Sweeney, C., and McGillis, W. R. (2009). Advances in quantifying air-sea gas exchange and environmental forcing Annu. Rev. Mar. Sci. 1, 213-244. doi: 10.1146/annurev.marine.010908.163742

Warzinski, R. P., Lynn, R., Haljasmaa, I., Leifer, I., Shaffer, F., Anderson, B. J., et al. (2014). Dynamic morphology of gas hydrates on a methane bubble in water: observations and new insights for hydrate film models. Geophys. Res. Lett. 41, 6841-6847. doi: 10.1002/2014GL061665

Westbrook, G. K., Thatcher, K. E., Rohling, E. J., Piotrowski, A. M., Pälike, H., Osborne, A. H., et al. (2009). Escape of methane gas from the seabed along the West Spitsbergen continental margin. Geophys. Res. Lett. 36, L15608. doi: 10.1029/2009GL039191

Whiteman, G., Hope, C., and Wadhams, P. (2013). Vast costs of Arctic change. Nature 499, 401-403. doi: 10.1038/499401a

Xiao, S. B., Yang, H., Liu, D. F., Zhang, C., Lei, D., Wang, Y. C., et al. (2014). Gas transfer velocities of methane and carbon dioxide in a subtropical shallow pond. Tellus B 66:23795. doi: 10.3402/tellusb.v66.23795

Yamamoto, A., Yamanaka, Y., and Tajika, E. (2009). Modeling of methane bubbles released from large sea-floor area: condition required for methane emission to the atmosphere. Earth Planet. Sci. Lett. 284, 590-598. doi: 10.1016/j.epsl.2009.05.026

Yoshida, O., Inoue, H. Y., Watanabe, S., Noriki, S., and Wakatsuchi, M. (2004). Methane in the western part of the Sea of Okhotsk in 1998-2000. J. Geophys. Res. 109, C09S12. doi: 10.1029/2003JC001910

Yvon-Lewis, S. A., Hu, L., and Kessler, J. (2011). Methane fux to the atmosphere from the deepwater horizon oil disaster. Geophys. Res. Lett. 38, L01602. doi: 10.1029/2010GL045928

Zhang, Y., Zhao, H. D., Zhai, W. D., Zang, K. P., and Wang, J. Y. (2014). Enhanced methane emissions from oil and gas exploration areas to the atmosphere - The central Bohai Sea. Mar. Pollut. Bull. 81, 157-165. doi: 10.1016/j.marpolbul.2014.02.002

Zhao, Z., Zhang, G. Y., Liang, T., Liang, Y. B., and Li, H. W. (2014). New exploration discovery and development trend of oil/gas exploration around the world in 2012. Nat. Gas Geosci. 25, 39-44.

Conflict of Interest Statement: The authors declare that the research was conducted in the absence of any commercial or financial relationships that could be construed as a potential conflict of interest.

Copyright (c) 2015 Zhang and Zhai. This is an open-access article distributed under the terms of the Creative Commons Attribution License (CC BY). The use, distribution or reproduction in other forums is permitted, provided the original author(s) or licensor are credited and that the original publication in this journal is cited, in accordance with accepted academic practice. No use, distribution or reproduction is permitted which does not comply with these terms. 